This item was submitted to Loughborough's Research Repository by the author.

Items in Figshare are protected by copyright, with all rights reserved, unless otherwise indicated.

\title{
Trade-offs in managing commercial consumer returns for online apparel retail
}

PLEASE CITE THE PUBLISHED VERSION

http://dx.doi.org/10.1108/IJOPM-01-2015-0010

\section{PUBLISHER}

(c) Emerald Group Publishing

\section{VERSION}

AM (Accepted Manuscript)

\section{PUBLISHER STATEMENT}

This work is made available according to the conditions of the Creative Commons Attribution-NonCommercialNoDerivatives 4.0 International (CC BY-NC-ND 4.0) licence. Full details of this licence are available at: https://creativecommons.org/licenses/by-nc-nd/4.0/

\section{LICENCE}

CC BY-NC-ND 4.0

\section{REPOSITORY RECORD}

de Leeuw, Sander, Beatriz Minguela-Rata, Ehsan Sabet, Jaap Boter, and Runa Sigurdardottir. 2019. "Tradeoffs in Managing Commercial Consumer Returns for Online Apparel Retail”. figshare. https://hdl.handle.net/2134/21134. 


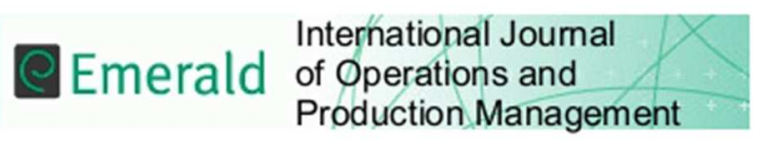

\section{Trade-offs in managing commercial consumer returns for online apparel retail}

\begin{tabular}{|r|l|}
\hline Journal: & International Journal of Operations and Production Management \\
\hline Manuscript ID & IJOPM-01-2015-0010.R3 \\
\hline Manuscript Type: & Research Paper \\
\hline Keywords: & Empirical, E-business, Logistics, Case study \\
\hline \multicolumn{2}{l}{} \\
\end{tabular}

SCHOLARONE ${ }^{\text {M }}$

Manuscripts 


\section{Introduction}

One of the key logistical challenges for online apparel retailers is the high volume of products returned by consumers (Wood, 2001). This requires a major reverse logistics operation (Aitken and Harrison, 2013). According to the Council of Supply Chain Management Professionals' glossary (2012), reverse logistics is: "A specialized segment of logistics focusing on the movement and management of products and resources after the sale and after delivery to the customer. Includes product returns for repair and/or credit. " Managing returns is usually a complex process for online apparel retailers and considerable effort has to be undertaken to rapidly refurbish the returned product in order to ensure quick availability for resale. With return percentages hovering around 30 percent and a total market size in US online apparel retail of over US\$40bn in 2013 already (Forbes, 2013), one can conclude that these days the returns challenge is enormous in online apparel retail.

In the online apparel retail industry, reverse flows from consumers are mainly caused by commercial agreements or legal/contractual obligations towards the consumers. Minimizing the rate of returns obviously is desirable for retailers; however, relaxing returns policies may also increase consumer satisfaction, thereby potentially increasing sales. Dholakia et al. (2005) argue that efficient and effective returns processes are even more relevant for online-only retailers (companies with a web presence but no physical stores, also referred to as pure players) than for conventional brick-and-mortar stores (offline retailers that only have physical stores but no web presence). The reason for this is that consumers often do not have the opportunity to physically examine the products before purchasing them. Evidence suggests that the costs of processing these returns on a per item basis is generally higher for online-only retailers compared to conventional multi-channel retailers. This is partly because conventional retailers can use their existing physical stores for gatekeeping returns, while online-only retailers need to establish new channels for returns. This may cause an increase in returns-processing costs (Grewal et al, 2004).

Ruiz-Benitez et al. (2014) argue that despite the increase in consumer returns over the past decade, research on return control policies has been limited. A search with keywords "consumer return" and ("b2c" AND "return") in November 2014 rendered only 29 hits on ISI Web of Knowledge, of which 25 were related to supply chain management in the broadest sense. Most of these papers are from the operations domain and mathematical in nature. Also more recent work focuses on mathematical modeling. For example, Chen and Chen (2015) published a study how multiple retailers with different leniency in customer returns policies can compete on price. Xu et al. (2016) focus on the dependence of consumer valuation on the return deadline set by retailers and develop pricing, refund and inventory policies dependent on this relation. Dominguez et al. (2015) find that the way returns impact supply chain dynamics strongly depends on the network configuration. A smaller number of papers report on marketing-focused studies. For example, Hjort et al. (2013) develop a customer segmentation based on sales and returns behavior, and Harris (2010) investigates how consumers exploit firms' returns policies. De Koster and Zuidema (2005) are one of a few that discuss an actual case study on the operations of consumer returns at a large online retailer. 
Although several authors have identified a need for more empirical research in the area of returns (Vachon and Klassen, 2010; Cohen et al., 2006) this gap is yet to be addressed. In the remainder of this paper we attempt to make a contribution to this call. We specifically focus on returns operations from a retailer perspective, rather than from a consumer perspective (for the latter see, e.g., Mollenkopf et al. (2007; 2011) or Griffis et al. (2012)). We aim to integrate the operations and marketing literature in this area by identifying both operations and marketing implications of our findings.

The existing literature is inconclusive on whether retailers should aim to avoid product returns to whatever extent possible, or aim to improve the capability of their operations to handle returns as efficiently as possible. Some argue returns avoidance should be a priority of retailers (Mollenkopf et al., 2007; Mollenkopf et al. 2011). Others, such as Mukhopadhyay and Seoputro (2004), assert that consumers with the ability to bring online purchases to a physical store will be more satisfied than those who cannot do so. This suggests that offering multiple options for returns while focusing on efficiencies in returns handling may increase retail revenues. In fact, as argued by Griffis et al. (2012, returns management is a 'balancing act', where tightening or liberalizing a returns policy will impact consumer behavior. Stock and Mulki (2009) posit that good product returns processing enables firms to maximize revenues while minimizing costs. We use this as our theoretical starting point and aim to identify how choices in the design of returns processes can contribute to both profit maximization and cost minimization. We therefore used a returns process model that is based on literature (Rogers and Tibben-Lembke, 1998; Stock, 2004; Stock and Mulki, 2009; Lambert et al., 2011; Verweij et al., 2008).

The analysis of trade-offs between avoiding returns as much as possible versus facilitating returns to increase sales revenue versus keeping costs of processing returns down is the key objective of our research. We aim to identify which returns practices online apparel retailers employ and why, and what their effects are. Our research question is "what is the effect of operational returns practices that online retailers employ on decreasing the number of returns, improving the efficiency of returns handling processes, and on increasing sales revenue?" We use a case study research design to identify and understand the impact of common returns practices and their trade-offs. This research considers: (1) commercial consumer product returns, which include defective products, products that do not fit the consumer, and products returned because of consumer regret (De Koster and Delfmann, 2007), and (2) retailers selling apparel products online, since these have particularly high returns rates (Mostard et al., 2004).

Our paper is structured as follows: In section two we present the research design; in section three we introduce theory related to reverse logistics processes, develop propositions, and present the results from the empirical data collected in our case studies; in section four we empirically validate and discuss the results; and in the last section we provide conclusions, limitations, and avenues for future research.

\section{Research design}

We deploy an exploratory research design to understand best practices in returns management, since little is known about good practices in this field. For exploratory research, case studies are often recommended (Eisenhardt, 1989; Meredith, 1993; Voss et 
al., 2002). We follow a research design similar to the study of De Leeuw and Fransoo (2009). We develop propositions that we empirically explore using multiple case studies in order to develop a conceptual model. We focus on the apparel industry not only due to their high returns rates. Industries with short product life cycles - such as apparel - are evolving quickly and are, hence, recognized as leaders in supply chain initiatives (Fine, 1998). Therefore, they may be expected to be leaders in returns practices as well.

We have followed well-established methodological guidelines (Eisenhardt, 1989; Flynn et al., 1990; Meredith, 1993; Voss et al., 2002; Yin, 2003) to increase the validity of our findings. We deployed a multiple case study design and aimed for between six and ten cases, a number generally considered to be sufficient in such a setting (see Eisenhardt (1989)). We used qualitative interviews in the Netherlands as our primary data collection method: six in-depth interviews (by phone and face-to-face) were conducted with companies in apparel e-commerce. An additional interview with a logistics consultant also was conducted in order to get a professional review on the companies' practices. All interviews were conducted using a protocol based on literature (see appendix A); all interviews were transcribed and coded. Additionally, respondents reviewed our interview records to validate the content. To ensure the validity of this research and to avoid bias, the questionnaire focused on returns operations performed in the Netherlands only. The reliability has been ensured by following an interview protocol, while allowing the respondents to expand on each of the questions from the protocol (Cooper and Schindler, 2008; Eisenhardt, 1989).

We followed the advise of Eisenhardt (1989) to select cases as polar types given the limited number of cases studied. We aimed to investigate both pure players and multichannel players. Companies were selected across different returns channels, returns rates, and company sizes (number of employees as well as number of offline stores). Table 1 characterizes the case study companies. PP1 and PP2 are pure-players, both offering a wide collection of children's clothing from premium brands. $\mathrm{MC} 1$ is a retailer specializing in women's apparel and lingerie. MC2 originally started as a local brick-andmortar store and added a web shop as an additional sales channel a few years ago. The company offers premium brand apparel and accessories for men and women. MC3 is a retailer that sells clothing for teenagers and children and has 120 stores in the Netherlands, Belgium, France and Luxembourg. In early 2012, the company opened a web shop offering the same assortment available in its physical stores. MF is a multinational apparel OEM, with own factory outlets including an online store, which specializes in sportswear and sports equipment. Finally, we interviewed a consultant with expertise in online apparel retail. 
Table 1: Overview of interviewees

\begin{tabular}{|c|c|c|c|c|c|}
\hline Company & Channels used & Returns \% & \# Employees & $\begin{array}{c}\text { \# Offline } \\
\text { stores }\end{array}$ & $\begin{array}{c}\text { Region where } \\
\text { active }\end{array}$ \\
\hline PP1 & Pure Player & $18 \%$ & 125 & 0 & Netherlands \\
\hline PP2 & Pure Player & Estimated 18\% & 28 & 0 & Netherlands \\
\hline $\mathrm{MC1}$ & Multi-Channel & $45 \%$ & 2400 & 130 & Netherlands \\
\hline $\mathrm{MC} 2$ & Multi-Channel & Estimated 18\% & $\begin{array}{c}\text { Between } \\
6-10\end{array}$ & 1 & Netherlands \\
\hline MC3 & Multi-Channel & $13 \%$ & 1500 & 120 & $\begin{array}{l}\text { Netherlands, } \\
\text { Belgium, France, } \\
\text { Luxembourg }\end{array}$ \\
\hline MF & $\begin{array}{c}\text { OEM+multi- } \\
\text { channel }\end{array}$ & $18 \%$ & $\begin{array}{c}\text { Appr. } \\
46.000 \\
\end{array}$ & 0 & Global \\
\hline Consultant & $\mathrm{n} / \mathrm{a}$ & - & 1 & - & Netherlands \\
\hline
\end{tabular}

We interviewed people with e-commerce and supply chain roles. The interviewees were E-commerce Coordinator, Operations Manager, Store Manager, Logistics Manager, Senior Vice President of Supply Chain Management, Owner and Logistics Consultant. The interview length varied from 1 hour to 2 hours and 10 minutes. We used a tape recorder during the interviews to gather as much information as possible. This enabled us to use quotes from the interviewees to support or elaborate on our interpretation of events.

To analyze the interview data we first used Atlas.ti software to identify the aspects of returns mentioned most by interviewees. This helped us identify the relevance of individual elements of the returns process. Interview data were then summarized in tabular form to structure and enhance the cross-case analysis. We summarized the interviews in tables identifying the following: a practice that applied to a part of the returns process (for example, providing the option to return items for free), the reason(s) for applying this practice, and the advantages and disadvantages of this practice mentioned by the interviewees. This allowed for a comparison of the perceived advantages and disadvantages of practices alongside their supporting arguments. The returns topics analyzed are in line with the process model developed in section 3: returns avoidance, gatekeeping of returns, collection of returns, sorting and inspection of returns, returns recovery, returns process improvements, returns network setup, returns options provided, and the use of free returns. Table 2 shows an example of a cross-case analysis table for the topic Returns Avoidance. 
Table 2. Cross-case analysis table - Returns Avoidance

\begin{tabular}{|l|l|l|l|l|}
\hline Practice & $\begin{array}{l}\text { Company } \\
\text { applying } \\
\text { practice }\end{array}$ & Why applied & $\begin{array}{l}\text { Advantages } \\
\text { mentioned }\end{array}$ & $\begin{array}{l}\text { Disadvantages } \\
\text { mentioned }\end{array}$ \\
\hline $\begin{array}{l}\text { No } \\
\text { gatekeeping }\end{array}$ & PP2 & $\begin{array}{l}\text { PP2 accepts all returns in } \\
\text { order to be flexible and } \\
\text { customer friendly. }\end{array}$ & $\begin{array}{l}\text { Easy returns will } \\
\text { lead to more } \\
\text { customers shopping } \\
\text { in the future at PP2. }\end{array}$ & $\begin{array}{l}\text { Large amount of } \\
\text { products in the } \\
\text { warehouse that need to } \\
\text { be sold at a discount. }\end{array}$ \\
\cline { 2 - 5 } & MC2 & $\begin{array}{l}\text { Company accepts all } \\
\text { returns since it is } \\
\text { expensive to send the } \\
\text { product back. }\end{array}$ & $\begin{array}{l}\text { Good customer } \\
\text { service. }\end{array}$ & $\begin{array}{l}\text { More likely selling } \\
\text { products at discount } \\
\text { because they are at the } \\
\text { end of its life span or } \\
\text { have bad quality. }\end{array}$ \\
\cline { 2 - 5 } & MC1 & $\begin{array}{l}\text { High level of customer } \\
\text { service is more important } \\
\text { than a few products sold } \\
\text { at a discount or scrapped. }\end{array}$ & $\begin{array}{l}\text { Easy for customers } \\
\text { to return products if } \\
\text { they change their } \\
\text { minds. }\end{array}$ & $\begin{array}{l}\text { Many products } \\
\text { scrapped. }\end{array}$ \\
\hline $\begin{array}{l}\text { Send } \\
\text { unauthorized } \\
\text { returns back } \\
\text { to customer }\end{array}$ & PP1 & $\begin{array}{l}\text { Gatekeeping is done } \\
\text { immediately when } \\
\text { products arrive to the } \\
\text { warehouse. If returns are } \\
\text { not allowed they are sent } \\
\text { back to consumer. }\end{array}$ & $\begin{array}{l}\text { Have fewer products } \\
\text { sold with markdown } \\
\text { because PP1 does } \\
\text { not accept returns } \\
\text { that do not comply } \\
\text { with the return } \\
\text { policy. }\end{array}$ & $\begin{array}{l}\text { High transportation } \\
\text { costs because of } \\
\text { sending products back } \\
\text { to customer. }\end{array}$ \\
\cline { 2 - 6 } & MF & $\begin{array}{l}\text { MF cannot sell returned } \\
\text { products against full } \\
\text { price in their web shop. }\end{array}$ & $\begin{array}{l}\text { Do not have } \\
\text { unsellable products } \\
\text { in the warehouse that } \\
\text { needs to be moved to } \\
\text { outlet. }\end{array}$ & $\begin{array}{l}\text { High transportation } \\
\text { costs. }\end{array}$ \\
\hline
\end{tabular}

In the next section we develop a process model and propositions based on literature, which we then verify using the interviews.

\section{Process model and proposition development}

Blumberg (2005) argues that consumer returns are often the result of impulsive buying, trying out a product, or checking how a product fits into existing environments. In apparel retail, consumers often order several sizes, colors or styles of the same product and return those they do not want (Kang and Johnson, 2009). For example, for the catalogue business at Victoria's Secret, a US lingerie retailer, most of the returns are the result of sizing issues (Rogers et al., 2002). Thus, a significant number of the returned products are in perfect condition for resale. The quantity of products returned is likely to be reinforced by the fact that consumers in the Netherlands (as in other EU countries) are legally entitled to fourteen business days to consider and return their online purchase (and receive their money back). Refund guarantees provide consumers the opportunity to change their minds about purchasing when their needs or expectations are not met (de Brito and Dekker, 2004). 


\subsection{The returns process}

Based on prior publications (Rogers and Tibben-Lembke, 1998; Stock, 2004; Stock and Mulki, 2009; Lambert et al., 2011; Verweij et al., 2008), we developed a model of reverse logistics processes for commercial online consumer returns (see Figure 1), which we then used as a framework to develop propositions. Below we elaborate on the individual process steps.

\section{$<$ INSERT FIGURE 1 ABOUT HERE $>$}

The process starts when a consumer returns a product. Consumer returns may need authorization before a return can be processed. Depending on the type of product, companies may issue a returns merchandize authorization (RMA) before a consumer is allowed to return items ( $\mathrm{Li}$ and Olorunniwo, 2008). This is an administrative process whereby the company verifies whether the consumer is entitled to return the product according to its returns policies. RMAs help companies to manage returns flows and facilitate the screening and disposition process. Stock and Mulki (2009) found that a majority of companies use some form of returns authorization processes.

The next step in the returns process is collection. Kumar and Putman (2008) argue that the method of returns collection is actually a key step of reverse supply chain designs. We consider three variants:

(1) The consumer drops the product at a physical store of the company. Clearly, this applies only to multi-channel retailers, not pure players. Using physical stores as a drop-off point may have considerable advantages, since consumers may be able to exchange their items but also buy additional products (Tarn et al., 2003).

According to Mukhopadhyay and Seoputro (2004), consumers who can return online purchases to physical stores are more satisfied than consumers who cannot.

(2) The consumer drops the package at a collection and drop-off point (CDP). A CDP may be any service point where consumer can pay, collect and return their parcels (e.g., a store, petrol station or post office). The use of CDPs has become more common in recent years (Agatz et al. 2008; McLeod et al. 2006; Globalwebshoplogistics, 2014). Consumers can indicate in their ordering process that they would like their online order delivered to a certain CDP for convenient collection of their online purchases. CDPs may also be used in the reverse direction: consumers are able to drop off returns at a CDP, which are then picked up by a carrier and delivered to the retailer.

(3) A carrier picks up the product at the consumer's address.

The subsequent step is screening, also referred to as gatekeeping, and consists of a basic screening of the returned merchandise, determining whether the return is valid, and whether the item can enter the reverse supply chain (Rogers et al., 2002). Appropriate gatekeeping methods ensure that a firm is not accepting unauthorized, invalid or unwanted returns. However, consumers who have been refused in the gatekeeping process may end up sending their products back to the company anyway, and the company must plan to deal with those surprise returns, as well. The company must determine the criteria for accepting a return (Lambert et al., 2011). We consider three 
possibilities:

(1) Centralized screening, in which all returned products are collected then forwarded to a central returns facility, where screening takes place.

(2) Decentralized screening, in which returned products are screened immediately at the drop-off point - typically, the physical store of the retailer.

(3) No screening, in which retailers have a policy of accepting all consumer returns.

Gatekeeping at stores can be difficult since store clerks often are not able to screen returns (Lambert, 2004). After screening, the destination of the product may be determined (disposition). Returns are split into distinct recovery option groups, primarily according to their quality characteristics (Guide and Van Wassenhove, 2002). In principle, disposition has three basic outcomes: the product is fit for resale and can be put into stock; the product can be made fit for resale after rework (repacking, refurbishing, repair, etc.); or the product is not fit for resale. In the last instance, the product is discarded, recycled, or disposed of in an alternative channel. Product disposition may take place in a central facility, after which it is put in central stock, sent to a rework facility, or disposed. Disposition can also be done in stores after decentralized screening. The main advantage of the latter approach is that the store clerk can restock the product immediately if it is fit for resale. This saves considerable logistics costs and time.

Finally, redistribution refers to the logistics activities required to transfer a product into a marketplace and/or the consumer (Kokkinaki et al., 2000). Here we may distinguish between different quality grades - for example, primary quality, which may be sold as a new product, and secondary quality, which may be sold only through certain channels or at a reduced price.

\subsection{Returns practices}

In conventional retail stores, front-line store personnel mostly carries out the screening of online sales returns. However, store personnel do not always have the capabilities to perform properly the gatekeeping procedures (Lambert, 2004). This is the primary reason research suggests that companies avoid returns as a priority in their reverse logistics strategy (Mollenkopf et al., 2007; Mollenkopf et al. 2011). Avoiding returns in a customer friendly manner requires that consumers/users clearly understand what they are purchasing. Consumers look for more aspects than price during the buying process (Bhatnagar and Ghose, 2004). Based on this understanding, we formulate our first proposition for managing online returns in fashion retail:

\section{Proposition 1: Providing appropriate and precise information on products prevents unnecessary returns.}

When dealing with returns, companies must decide who pays for logistics handling of returned products. Any decisions must be in line with the customer service strategy set by the company (Lambert et al., 2011) and must comply with legal statutes. Some online retailers have installed equity-based returns policies, requiring consumers to pay for shipping and handling of returned products when retailers determine that consumers are 
at fault (Bower and Maxham, 2012). E-commerce retailers often offer free shipping (including on returns) if consumers spend more than a set minimum (Rogers et al., 2002). In these cases, consumers may spend more than the required amount only to get free shipping with the intention of returning the unwanted items. From the retailer's point of view, offering a generous returns policy may increase revenues but may also increase costs due to increased returns (Kang and Johnson, 2009).

Providing accurate information on returns to the consumers and exercising a liberal returns policy has the objective of creating loyal customers, thereby increasing sales (Hjort et al. 2013). A more liberal returns policy increases returns (Wood, 2001) and results in more fraudulent returns (Harris 2010); however, consumers appreciate being able to return an item easily if it does not meet their expectations (Mukhopadhyay and Setoputro, 2004).

Bower and Maxham (2012) find that consumers needing to pay a fee for their product returns will decrease their repurchases while those receiving free returns will increase their repurchases. They conclude that if the aim is to increase sales it is beneficial for retailers to institute a free returns-shipping policy (Bower and Maxham, 2012). Based on this conclusion, we develop our second proposition:

Proposition 2: Offering free returns increases repurchasing, consumer satisfaction and revenue for the retailers.

Sen (2008) and Tarn et al. (2003) state that multi-channel retailers have a benefit over pure players by offering consumers the option to return items to one of their physical stores rather than at a designated third-party collection and drop-off point (CDP), such as those operated by the company DHL. In recent years, the market has seen a surge in both the number of CDPs available and the number online retailers offering pick-up and collection via CDPs (Globalwebshoplogistics, 2014). This is in line with Mukhopadhyay and Seoputro (2004) who state that consumers offered the option to bring online purchases to a physical store will be more satisfied than those not offered this option. Based on this insight, our third proposition is developed as follows:

Proposition 3: Offering consumers multiple collection options to return their products increases consumer satisfaction.

Blackburn et al. (2004) present two means by which to organize the returns process: a centralized and a decentralized reverse supply chain structure. The main difference between a centralized and decentralized structure is where gatekeeping takes place. In a centralized structure, all returned products are delivered first to a central facilitytypically, a return center-for receipt, screening, and disposition. Rogers and TibbenLembke (1998) stress the importance of such centralized returns centers for achieving economies of scale in processing and transportation, and for minimizing costs. In a decentralized structure, product returns are handled directly by retailers or returns facilities located nearby consumers. Gatekeeping is a time consuming process and may require skilled employees. Performing gatekeeping at retail stores could, therefore, increase labor costs (Skjøtt-Larsen et al., 2007). However, according to Blackburn et al. 
(2004) a decentralized structure is more effective for time-sensitive products since returned products can proceed much quicker to the next step in the process. As a result, value can be recovered in a timely manner. To investigate this trade-off, our fourth proposition is formed as:

\section{Proposition 4: Decentralizing gatekeeping increases effectiveness of returns handling.}

A majority of companies view the handling of product returns as a nuisance (Blackburn et al., 2004) and most reverse supply chains have been designed with a primary purpose to minimize the overall costs of product recovery (Blackburn et al., 2004). However, Griffis et al. (2012) stresses the importance of targeting short product handling times in reverse supply chains. They show that fast returns processes are correlated with customer retention, increased purchase frequency, and purchase amount. Moreover, Blackburn et al. (2004) introduce the concept of marginal value of time (MVT), or the rate of product value decline after market introduction. Time-sensitive products have a high MVT, which means that they can lose their value quickly. MVT may be even higher as a product approaches the end of its life cycle (Hwan and Rho, 2008). Apparel products have a high MVT because they tend to decrease in value during the season and are highly discounted after the season ends (Ferdows et al., 2004). In general, after the end of the selling period, returns are usually disposed or sold at a lower price in a secondary market. Therefore, in the apparel industry, if returned products cannot be resold quickly and efficiently, their value may decrease very quickly. Hence, quick returns processing is important in the apparel industry. Our fifth proposition addresses this issue as follows:

\section{Proposition 5: Fast returns processes maximize the expected market value of returned products.}

All propositions have been summarized in Table 3. In the next section, we discuss our case study results for all the propositions.

Table 3: Research propositions based on literature.

\begin{tabular}{|c|c|c|}
\hline$\#$ & Proposition & Reference \\
\hline 1 & $\begin{array}{l}\text { Providing appropriate and precise information on } \\
\text { products prevents unnecessary returns }\end{array}$ & $\begin{array}{l}\text { Rogers et al., 2002; } \\
\text { Lambert et al., } 2011\end{array}$ \\
\hline 2 & $\begin{array}{l}\text { Offering free returns increases repurchasing, consumer } \\
\text { satisfaction and revenue for the retailer }\end{array}$ & Bower and Maxham, 2012 \\
\hline 3 & $\begin{array}{l}\text { Offering consumers multiple collection options to } \\
\text { return their products increases consumer satisfaction }\end{array}$ & Sen, 2008 \\
\hline 4 & $\begin{array}{l}\text { Decentralizing gatekeeping increases effectiveness of } \\
\text { returns handling }\end{array}$ & Blackburn et al., 2004 \\
\hline 5 & $\begin{array}{l}\text { Fast returns processes maximize the expected market } \\
\text { value of returned products }\end{array}$ & $\begin{array}{l}\text { Blackburn et al., 2004; } \\
\text { Guide et al., 2006; } \\
\text { Hwan and Rho, } 2008\end{array}$ \\
\hline
\end{tabular}


4. Empirical validation and discussion

We first describe which elements of a returns process interviewees deemed important. To do so we used Atlast.ti to code and analyse the content from the interviews. Table 4 shows the ten most used (counted) words from the interviews.

Table 4: Overview of the most frequently used words in the in-depth interviews.

\begin{tabular}{|l|l|}
\hline Keyword & Frequency in interviews \\
\hline Warehouse & 70 \\
\hline Information & 64 \\
\hline System & 60 \\
\hline Service & 54 \\
\hline Improvement & 43 \\
\hline Costs & 42 \\
\hline Ship & 42 \\
\hline Policy & 38 \\
\hline Quality & 38 \\
\hline Free & 27 \\
\hline
\end{tabular}

The word 'warehouse' was the most frequently used word in the in-depth interviews. Interviewees mentioned that effective warehouse operations are critical to process product deliveries and returns. This finding is in line with Stock and Mulki (2009) who found that in returns processes a significant amount of time is spent on warehouse activities. The words 'information' and 'systems' also were used often. The interviewees argued that an efficient information and technological system is vital for supporting returns processes, which is in line with the research findings of Ravi and Shankar (2004)

Interviewees used the word 'service' in the context of a company's customer service. Interviewees for example mentioned that being flexible with returns authorizations, offering easy returns methods and providing customers with adequate information about the returns process are important aspects of providing good customer service. However, many of the interviewees also mentioned that improvements are required in returns processes in order to increase customer satisfaction and reduce costs. During the interviews it was argued that one way to reduce costs is by negotiating more beneficial service-level agreements with carriers in order to lower the costs of 'shipping' - another frequently mentioned word.

The word 'policy' was used in the context of returns policy. Interviewees argued that customers should be able to look up the terms and conditions for returning a product on their website before purchasing products. A returns policy may prevent late returns and also inform customers about the company's right to refuse certain returns. Such standards for returns are necessary for efficient and effective returns processing (Stock and Mulki, 2009). The word 'free' occurred in discussions concerning the question of whether or not companies should accept returns free of charge.

Following word-use analysis, we analyzed the content of the interviews to evaluate our propositions. The results of this analysis are presented below.

Proposition 1: Providing appropriate and precise information on products prevents 
This proposition implies that a better understanding of the sources and reasons behind returns may help design order-to-delivery processes that are better suited to reduce returns and even avoid returns entirely. However, according to $\mathrm{MC} 1$, it is almost impossible to avoid returns of apparel products because consumers are always uncertain about size, fit and color of products bought online. This is also identified by Rogers et al. (2002), who suggest that in order to solve this problem retailers and suppliers must work together closely to develop and apply uniform sizing guidelines across all products. Company PP1 mentioned that their primary goal is to reduce the number of returns; and they are working towards this goal by improving information about their products on their website. "We talked with our suppliers and obtained better size charts, so that out consumers would have more information" (PP1). According to PP1 this considerably reduces returns due to sizing problems - the largest category of returns for PP 1.

Unnecessary returns also consist of products that are not allowed to be returned. Gatekeeping is necessary to avoid such returns. We observed that some companies do not execute gatekeeping to keep unauthorized returns out, because of their service standards and because of the costs of sending unauthorized returns back to consumers. MF mentioned that they have a warehouse management system that validates if products are allowed in the reverse stream. Similar to MC2, MF mentioned that, "The consumer can ship back whatever they want, but there is a time limitation ... But the way it is handled internally is that, ... even if the return exceeds the time limitation, if the value of the product is very low we decide not to ship it back-because it is just too costly for us to ship it back and tell the consumer that he shouldn't have sent it." In line with company PP2, company MC1 argued, "Our customers are always right; consumer satisfaction is more important than the loss of some goods." Companies set time limitations with their returns policy, "but if people want to return, they return it anyhow" (MC2). According to $\mathrm{MC2}$, it is too expensive for the company to spend time calling and sending consumers emails if they return unauthorized products. In addition, it is also very expensive for the company to transport unauthorized products back to the consumers. MC2 says they "need to think what is better for the company, to send the product back or just keep it [...] it costs more money for us to send it back again so that is why we do allow the returns."

The interviews showed that there is a need for striking a balance between providing liberal returns policies versus accommodating the costs and efforts associated with handling returns. Liberal returns policies may in addition not only increase costs but they can also increase the occurrence of fraudulent returns. One way to mitigate fraudulent returns is to maintain a database of how often individual consumers have returned products. Consumers who do not return may then be offered rebates on future purchases, which are not offered to consumers who frequently return items. This is also highlighted by Ferguson et al. (2006), who discuss a contract between a manufacturer and a retailer to coordinate false consumer returns. A more recent technological development aimed at reducing returns is an online fitting room, which enables consumers to try out an item digitally, thereby increasing the chances that the item will actually fit (McFarland, 2014). The examples above highlight the importance of providing accurate information about product characteristics in order to reduce unnecessary returns. The interviews 
furthermore suggest that it is necessary to provide appropriate information about returns processes and procedures in order to reduce returns that are not allowed; install systems to discourage people to return products they are not allowed to return; and strike a balance between the costs of gatekeeping and inadvertently accepting unauthorized returns.

Proposition 2: Offering free returns increases repurchasing, consumer satisfaction and revenue for the retailer

Not all of our case companies agreed that offering free returns is a good option and a best practice for managing consumer returns. PP1 mentioned that "...the e-consumers are getting a little spoiled," since an increasing number of companies in the apparel ecommerce industry are offering free delivery and returns. PP2 stated, "Companies need to create some barriers so returns are not too easy." For example, PP2 mentioned that they require customers to pay the costs for product returns when retailers determine that consumers are at fault. On the other hand, PP2 indicated that they absorb the returns costs when they (or their suppliers) are at fault (e.g. due to product quality failure or late delivery). PP1 mentioned that it is too expensive for their company to offer free product returns and that their strategy, instead, is to keep consumers happy: "We don't want to be the cheapest, we want to be the best in service" (PP1). Similarly, the consultant stated, "There is no way that Dutch players can offer free deliveries and returns in the long term. Companies should rather focus on selling their product cheap, deal with the quality of their products [...] because they will always have returns [...] and it is too expensive to offer free returns".

Returns policies in the EU are constrained by law. The EU stipulates that consumers are entitled to receive their full product and shipping costs back if they return their items within 14 days upon receipt of the item. However, also in countries where the law does not stipulate a minimum length of cooling-off periods, such as the USA or Australia, consumers are offered 14-28 days to return an item (Globalwebshoplogistics, 2013). However, the policy of charging a restocking fee to consumers upon returning a product, which is common among many US online retailers, is not lawful in the EU. Many multichannel retailers provide an option to return items purchased online for free via a store (Globalwebshoplogistics, 2014), but this depends on the country. In fact, even within the same international companies, returns policies may differ per country. H\&M in the USA for example does not allow returning online purchases via H\&M stores, whereas this is a common practice for H\&M in the UK. ${ }^{1}$ This may be related to the fact that in-store pickup of online orders is not as common in the US as it is in the UK (Globalwebshoplogistics, 2014). Although a free returns option may be appealing to the

\footnotetext{
${ }^{1}$ We came to this conclusion by comparing the websites of H\&M in the UK and in the USA: http://www.hm.com/gb/customer-service/returns and http://www.hm.com/us/customer-service/returns-for-online-purchases
} 
consumers, it may lead to an increase in returns and thus costs.

\section{Proposition 3: Offering consumers multiple collection options on their return products} increases consumer satisfaction

Company MC1 and MC3 mentioned that approximately half of the product returns from the online shop are returned via the company's stores. MCI said, "We have a great opportunity with our stores. We receive about 45 percent total returns and 50 percent of these are returned in the stores. The consumer can now also see other new articles again and that is a unique resell system." PP1 also mentioned that having a physical store that can accept returns is good for sales: "Some companies are doing a cross channel strategy; they have their own shops for consumer returns. That is a good strategy, because then when the consumer brings something back he will buy a new product."

MC3 has not fully developed the returns infrastructure to handle product exchanges in their EDC. Similarly, MC2 does not have the information technology available for consumers to initiate a product exchange online. The pure players state that multi-channel retailers have great opportunity offering consumers the option to return to their shops. (PP1). PP2 mentioned that having a physical shop as a drop-off point for returned items is consumer friendly and an advantage for the consumer in order to easily find new and more suitable products.

It is important to realize that companies need the infrastructure to handle integration of these various channels. According to the interviewed consultant, multi-channel companies should expand their channel approach and offer returns via their stores as well as returns straight from consumer to returns center. Pure players and multi-channel retailers rely on the large parcel carriers in the Netherlands, such as PostNL and DHL, to collect returned products and transport them to the warehouse where the products are processed. The choice of carrier depends on the location of the returned products, the services the carriers offer, and the costs of those services. Companies PP2 and MC3 have a small volume of returns, and the interview revealed they do not feel the need to use more than one carrier to collect the products. On the other hand, MF has a large volume of returns, but only uses one carrier, due to amongst others the large number of carrier service points that are able to serve as collection points for returned items. The higher the number of collection points, the higher the level of customer service the company is offering, according to $\mathrm{MC} 1$. Company $\mathrm{MC} 1$ also mentioned that collecting products from wherever the customers prefer is perceived as a great customer service. This is in line with PP1's strategy to make returns easier for customers by providing many different return options and prices: "Collection at home is very interesting. Some web shops do it. ... It is more expensive for the customer, but it is very interesting for the customer to indicate where to pick up the return." PP1 wants to make home pick up available for its customer in the near future. In fact, German websites already provide more opportunities for home pickup of consumer returns than webshops in other parts of Europe (Globalwebshoplogistics, 2013; 2014). MC2 and MC3 indicated that they have difficulties in processing product exchanges in their online processing facilities. Instead, they suggest that consumers go to their physical store to (hopefully) exchange their items for other more suitable products. "Exchange is not possible in the distribution center 
because there is no contact with the customer and the chances of mistakes are bigger," says MC3. Therefore, the returns are collected at their stores and transported to a warehouse where all returns are processed.

Overall, providing multiple options for returning items may to contribute to the intention to repurchase. In addition, increasing in-store returns may be beneficial since it provides an opportunity for cross-selling to consumers (Tarn et al. (2003)). Both multichannel players and pure players in our study acknowledge this.

\section{Proposition 4: Decentralizing gatekeeping increases effectiveness of returns handling}

According to Blackburn et al. (2004), a decentralized network structure is better for timesensitive products such as apparel products, since returned products can be handled and processed immediately and, therefore, more value can be captured. Company MC1 is the only company that has a decentralized returns system. The products never leave the facility where they are returned, and all information is shared with other returns facilities in an integrated system. The company accepts all returns and therefore they do not need to train store employees to inspect and validate the returns (the gatekeeping). The decentralized structure allows the company to provide fast product handling and fast product refunds (when products are returned to a store). Nevertheless, a centralized returns system, in which all returns are processed in a centralized facility, is potentially more capable of minimizing the costs of returns processes. In this situation it is easier to standardize the operations and to minimize labor costs related to the inspection process (Rogers and Tibben-Lembke, 1998). PP1 mentioned that since all returns processes are done in one location, they can more quickly identify problems in the returns process and make improvements. PP1 also stated that since the returns department, quality control department, and customer service department are all located in the same place (at the returns function), they can jointly analyze problems and find solutions. This is in line with the following MC2 statement: "The three employees that we have [...] receive all emails and calls from our customers and they know everything about their situation;" As a result, MC2 argued, it is easy for these employees to find solutions and have efficient returns processing.

The appropriate level of decentralization of a returns network is influenced by the type of product. Time-sensitive products require fast turnaround processing, for which

decentralized networks may be more beneficial. Some products are also easier than others to assess. For example, it is difficult to check what the status is of electronics without expertise on the product. Such expertise is typically not available in store, though this may be covered through information systems. The interviews furthermore show that decentralization requires an appropriate information system infrastructure so that goods returned in store can be made available to online consumers again.

Proposition 5: Improving the speed of the returns process maximizes the expected market value of returned products

An interviewee at PP1 mentioned that a director of their carrier once said, "If you want to have a good webshop, you have to be good in returns and speed up the process." PP1 
suggested that their biggest improvements are in decreasing the number of manual steps in order to improve returns handling time: "We have to reduce the number of steps, make it simple." This is in line with other companies' responses. Company PP1 also stated that asking consumers to register a reason for the returns online, prior to returning the item, has streamlined the returns process and decreased the number of manual steps. The consultant furthermore mentioned that asking a consumer to provide a return reason is one of the most critical steps for companies as it keeps the returns process transparent. "It's about the advantages of knowing what is coming, know the value of the return, and it is really important to know what you are expecting" (Consultant). On the other hand, the interviewee at company MF characterized their company as more consumer-friendly because they don't require consumers to take the extra step of registering a return online: "You simply can pack it, fill in the documents that are in the package, bring it to the post office, and then it is over. "However, MF admits that requiring consumers to provide a return reason on the web before returning the item would allow the company to be more efficient, which is becoming increasingly important for the business, saying: "I believe that obviously from the DC perspective we are losing some time by having to handle documentation. The more you need to do manually the more time it takes and the higher the chances of mistakes."

All interviewees mentioned that sorting and inspection upon receiving a returned item is labor intensive, takes time and all products have to be thoroughly inspected. "We really check it very well, because that also gives us fewer new returns, " stated the interviewee at company PP1. A Warehouse Management System can help retailers organize the handling of product returns. However, "returns is still a process which requires checking something with the hands, and manual data input in the computer" (PP1).

The overall picture from the interviews is that speed is essential to returns processing. Speeding up the process can be done by providing consumer friendly returns processes that are easy to execute for consumers. However, this may also increase the number of products returned. Overall, reducing the internal throughput time of returns processing is necessary. Longer process time means capital tied up in stock for a longer period of time and means that these items cannot be used for sales purposes. Particularly in the fashion industry, this may be a serious problem since people often buy multiple sizes or colors of the same style, keep only one, and return the rest. To speed up this cycle, the company Jeansonline. $\mathrm{nl}^{2}$, for example, provides the option to have the delivery person wait 15 minutes to allow the customer to try on the items (trademarked as the 'easy fit \& return' service). It is easy for consumers to be able to hand back unwanted items immediately to the delivery person and the webshop thus has quicker access to returned items.

\section{Conclusions and recommendations}

In this paper we aimed to identify what the effects are of returns management practices that online apparel retailers employ on reducing consumer returns, achieving efficiency in handling consumer returns, and/or increasing sales revenues. We developed five propositions, which we have empirically verified. We use these propositions to develop a conceptual model, depicted below in Figure 2. This conceptual model shows the potential

${ }^{2}$ See shipment methods section on www.jeansonline.nl/info/shipment.html (in Dutch) 
relationships and options we found. The numbers in Figure 2 refer to the numbers in the text below.

\section{$<$ INSERT FIGURE 2 ABOUT HERE $>$}

First, all respondents indicated it is important to provide as accurate information to consumers as possible in advance of their purchase, with regard to sizes, colors, styles and other product and service specifications. This will reduce the number of products returned and thus reduce unnecessary returns (arrow 1 in Figure 2). To further reduce returns it is necessary to provide upfront appropriate information about returns processes and procedures, an area where web shops generally can improve (Global Webshop Logistics, 2014). This also requires implementation of systems to discourage people from returning products they are not allowed to return, (e.g., fraudulent returns as discussed by Ferguson (2006) and Harris (2010)). Finally, it is necessary to strike a balance between the costs of gatekeeping and inadvertently accepting unauthorized returns. As argued by Griffis et al. (2012) many online retailers struggle with gatekeeping, ensuring that only legitimate returns are accepted, yet it is key that return policies enable clear distinguishing between legitimate and illegitimate returns.

Second, we addressed how flexible an online retailer should be in offering free consumer returns options. Offering free shipping for returns may lead to more satisfied customers, leading to more returns (arrow 2) and potentially increased sales (arrow 3). Being flexible in accepting returns and providing consumers with a variety of means to support their returns may lead to loyalty and, thus, increased sales for the retailers; however, it requires an efficient returns process to keep costs down.

Third, we discussed making available to consumers multiple options to return items. This is expected to contribute to repurchasing intentions (arrow 4), yet it is more costly to operate (arrow 5). Both multichannel players and pure players in our study acknowledged that the stimulation of in-store returns may be particularly beneficial since it provides an opportunity for cross-selling to consumers, as also argued by Tarn et al. (2003).

Fourth, we discussed decentralization of gatekeeping. As argued by Ruiz-Benitez et al. (2014), decentralized gatekeeping is particularly well suited to the fashion sector since one can quickly spot defects with minimum training. This is not the case, for example, in the case of consumer electronics. The advisable level of gatekeeping decentralization is related to the product type and available information infrastructure, among other factors. As argued by Rogers and Tibben-Lemke (1998), a centralized returns system is more capable of minimizing costs of returns processes due to, for example, standardization of processes (depicted in arrow 6). Only one of the interviewees used decentralized gatekeeping, while also relying on an information infrastructure that made returned items available to other stores and to online consumers quickly.

Decentralized gatekeeping does contribute to speed, which was the fifth and last proposition discussed. All interviewees agreed that speed is essential to returns processing of fashion items because they are time-sensitive products. Fast processing of 
returns may lead to faster restocking of returned products and, therefore, may increase revenue potential (arrow 7); however, processing costs may be higher (arrow 8).

Our results must be interpreted with some caution. First, data collection in our case studies is subject to bias as with any interview (Saunders et al., 2009). A survey based on the conceptual model presented in Figure 2 could be helpful to reduce this bias and test the propositions on a large sample. This also enables determining which relationships from the conceptual model in Figure 2 are applicable to which type of retailer and in which type of situation. Our results have furthermore not been triangulated with transaction data on actual consumer returns; triangulation with such data will further enhance findings. The research is also limited by the fact that we studied Dutch locations of companies, which are all bound by European laws on consumer returns. As such a European perspective influences the results. The study is furthermore limited by focusing on commercial returns from consumers in the field of apparel e-commerce retailing. Future research may encompass a broader set of products than apparel. Last, in our study we present a retailer perspective. Our study does not discuss the social impact of returns. Future research in this area would be worthwhile. Performing a similar study from a consumer perspective on similar topics may reap additional interesting insights. 


\section{REFERENCES}

Agatz, N.A.H., Fleischmann, M. and A.E.E. van Nunen, J. (2008), E-fulfilment and multi-channel distribution - A review, European Journal of Operational Research, 187, 339-356.

Aitken, J. and Harrison, A. (2013), Supply governance structures for reverse logistics systems, International Journal of Operations \& Production Management, 33(6), 745-764.

Bhatnagar, A. and Ghose, S. (2004), A latent class segmentation analysis of eshoppers, Journal of Business Research, 57, 758-767

Blackburn, J.D., Guide Jr., V.D., Souza, G.C. and Van Wassenhove, L.N. (2004), Reverse supply chains for commercial returns, California Management Review, 4 6(2), 6-22.

Blumberg, D.F. (2005), Introduction to Management of Reverse Logistics and Closed Loop Supply Chain Processes, New York: CRC Press.

Bower, A.B. and Maxham, J.G.II. (2012), Return Shipping Policies of Online Retailers: Normative Assumptions and the Long-Term Consequences of Fee and Free Returns, Journal of Marketing, 76 (September 2012), 110-124.

Browne, M. (2001), E-commerce and urban transport, paper presented at the OECD/ECMT Seminar the Impact of e-Commerce on Transport, Paris, June 56.

Chen, J., \& Chen, B. (2015), Competing with customer returns policies. International Journal of Production Research, DOI: 10.1080/00207543.2015.1106019.

Cohen, M.A., Agrawal, N. and Agrawal, V. (2006), Winning the aftermarket, Harvard Business Review, 84(5), 129-138.

Cooper, P.S. and Schindler, D.R. (2008), Business Research Methods, $8^{\text {th }}$ edition, New York: NY, McGraw-Hill.

Council of Supply Chain Management Professionals, (2012), Glossary of Terms. Retrieved June 14, 2012 from http://cscmp.org/digital/glossary/glossary.asp.

De Brito, P.M. and Dekker, R. (2004), A Framework for Reverse Logistics, In: Dekker, R, Fleischmann, M., Inderfurth, K. and van Wassenhove, L.N. (eds), Reverse logistics: Quantitative Models for Closed-Loop Supply Chains. Rotterdam: Springer.

De Koster, M.B.M. (2001), The logistics behind the enter click. In: A Klose, LN Van Wassenhover (Eds), Quantitative Approaches to Distribution Logistics and Supply Chain Management, Springer: Berlin: 2002, 131-148. 
De Koster, R. and Delfmann, W. (2007). Managing supply chains - challenges and opportunities (1st edition). Gylling: Copenhagen Business School Press.

De Koster, R.B.M. and Zuidema, J.P. (2005), Commercial returns in a mail order company: the Wehkamp case. In: Flapper, S., van Nunen, J. and Van Wassenhove, L., (2005 edition), Managing Closed-Loop Supply Chains. Springer, Berlin: Heidenberg.

De Leeuw, S. and Fransoo, J. (2009), Drivers of close supply chain collaboration: one size fits all?, International Journal of Operations \& Production Management, 29 (7), 720-739.

Dholakia, R., Zhao, M. and Dholakia, N. (2005), Multi-channel retailer: A case study of earlier experiences, Journal of Interactive Marketing, 19 (2), 63-74.

Dominguez, R., Cannella, S. and Framinan, J.M., 2015), On returns and network configuration in supply chain dynamics, Transportation Research Part E: Logistics and Transportation Review, 73, pp.152-167.

Eisenhardt, K.M. (1989), Building theories from case study research, Academic Management Review, 14(4), 532-550.

Ferguson, M. Guide, Jr., V.D.R, Souza, G.C. (2006), Supply Chain Coordination for False Failure Returns, Manufacturing \& Service Operations Management 8(4), 376-393.

Ferdows, K., Lewis, M. A., and Machuca, J. A. (2004). Rapid-fire fulfillment. Harvard business review, 82 (11), 104-117.

Fine, C.H. (1998), Clockspeed: Winning industry control in the age of temporary advantage, Perseus Books, New York, NY.

Flynn, B.B., Sakakibara, S., Schroeder, F.G., Bates, K.A. and Flynn, E.J. (1990), Empirical research methods in operations management, Journal of Operations Management, 9 (2), 250-284.

Forbes (2013), US Online Retail Sales To Reach \$370B By 2017; \$191B in Europe, Retrieved from http://www.forbes.com/sites/forrester/2013/03/14/usonline-retail-sales-to-reach-370b-by-2017-e191b-in-europe/, accessed June 2014.

Globalwebshoplogistics (2013), “Global webshop logistics onderzoek 2013: 1000 webshops investigated on logistical capabilities", retrieved from www.globalwebshoplogistics.com.

Globalwebshoplogistics (2014), “Global webshop logistics onderzoek 2014; de eerste onderzoeksresultaten" (in Dutch), retrieved from www.globalwebshoplogistics.com. 
Grewal D., Iyvr, G.R. and Levy, M. (2004), Internet retailing: Enablers, limiters, and market consequences, Journal of Business Research, 57(7), 703-713.

Griffis, S., Rao, S., Goldsby, T. and Niranjan, T. (2012), The customer consequences of returns in online retailing: An empirical analysis, Journal of Operations Management, 30(4), 282-294.

Guide, Jr., V.D.R. and van Wassenhove, L.N. (2002), Closed-Loop Supply chains: Ractices and Potential, Special Issue The Reverse Supply Chain, Harvards Business Review, 80(2), 25-26.

Guide, V.D.R. Jr., Souza, G.C., van Wassenhove, L.N. and Blackburn, J.D. (2006), Time Value of Commercial Product Returns. Management Science, 52(8), 12001214.

Harris, L.C. (2010), Fraudulent consumer returns: exploiting retailers' return policies, European Journal of Marketing, 44 (6), 730-746.

Hjort, K., Lantz, B., Ericsson, D., and Gattorna, J. (2013), Customer segmentation based on buying and returning behavior, International Journal of Physical Distribution \& Logistics Management, 43(10), 852-865.

Hwan, Y.M. and Rho, J.J. (2008), RFID System for Centralized Reverse Supply Chain in the Apparel Industry, Information and Communications University Daejeon, Korea.

Kang, M. and Johnson, K. (2009), Identifying characteristics of consumers who frequently return apparel, Journal of Fashion Marketing and Management: An International Journal, 13(1), 37-48.

Kokkinaki, A.I. Dekker, R., Nunen, J.A.E.E.V. and Papis, C.P. (2000), An explanatory study on electronic commerce fro reverse logistics, Supply Chain Forum, An International Journal, 1, 10-17.

Kumar, S. and Putnam, V. (2008), Cradle to cradle: reverse logistics strategies and opportunities across three industry sectors, International Journal of Production Economics, 115(2), 305-315.

Lambert, D.M. (2004), The eight essential supply chain management processes, Supply Chain Management Review, 8(6), 18-26.

Lambert, S., Riopel D. and Abdul-Kader, W. (2011), A Reverse Logistics Decisions Conceptual Framework, Computers \& Industrial Engineering, 61(3), 561-581.

Li, X. and Olorunniwo, F. (2008), An exploration of reverse logistics practices in three companies, Supply Chain Management: An International Journal, 13 (5), 381-386. 
McFarland, M (2014), Returns plague fashion e-commerce. Can technology fix the problem?, The Washington Post, March 28, available at http://www.washingtonpost.com/blogs/innovations/wp/2014/03/28/retu rns-plague-fashion-e-commerce-can-technology-fix-the-problem/, accessed June 2014.

McLeod, F., Cherrett, T. and Song, L. (2006), Transport impacts of local collection/delivery points, International Journal of Logistics Research and Applications, 9 (3), 307-317.

Meredith, J. (1993), Theory building through conceptual methods, International Journal of Operations \& Production Management, 13 (5), 3-11.

Mollenkopf, D., Russo, I. and Frankel, R. (2007), The returns management process in supply chain strategy, International Journal of Physical Distribution \& Logistics Management, 37(7), 568-592.

Mollenkopf, D.A., Frankel. R. and Russo, I. (2011), Creating value through returns management: Exploring the marketing-operations interface, Journal of Operations Management, 29 (5), 391-403.

Mostard, J., de Koster, R. and Teunter, R. (2004). The distribution-free newsboy problem with resalable returns, International Journal of Production Economics, 97(3), 329-342.

Mukhopadhyay, S.K. and Setoputro, R. (2004), Reverse logistics in e-business: Opimal price and return policy, International Journal of Physical Distribution \& Logistics Management, 34(1), 70-89.

Ravi, V. and Shankar, R. (2004), Analysis of interactions among the barriers of reverse logistics, Technological Forecast \& Social Change, 72(8), 1011-1029.

Rogers, D.S., and Tibben-Lembke, R.S. (1998), Going Backwards: Reverse Logistics Trends and Practices, Reverse Logistics Executive Council, Reno, USA.

Rogers, D.S., Lambert, D.M., Croxtons, K.L. and Garcia-Dastugue, S. J. (2002), The Return Management Process, The International Journal of Logistics Management, 13(2), 1-18.

Ruiz-Benítez, R., Ketzenberg, M., and van der Laan, E. A. (2014), Managing consumer returns in high clockspeed industries, Omega, 43, 54-63.

Saunders, M., Lewix, P. and Thornhill, A. (2009), Research Methods for Business Students, $5^{\text {rd }}$ edition, Harlow: Prentice Hall.

Sen, A. (2008), The US fashion industry: A supply chain review. Department of Industrial Engineering, Bilkent Univeristy, Turkey. 
Skjøtt-Larsen, T., Schary, P., Mikkalo, J.H. and Kotzab, H. (2007), Managing the Global Supply Chain (3rd Edition), Copenhagen: Copenhagen Business School Press.

Stock, J.R. (2004), Product Return/Reverse Logistics in Warehousing: Strategies, Policies and Programs, Oak, Brook, IL: Warehousing Education \& Research Council.

Stock, J.R., and Mulki, J.P. (2009), "Product Return/Reverse Logistics in Warehousing: Strategies, Policies and Programs”, Journal of Business Logistics, 30 (1), 33-62..

Tarn, J.M., Razi, M.A., Wen, H.J. and Perez, A.A. (2003), E-fulfilment: the strategy and operational requirements, Logistics Information Management, 16(5), 350-62.

Vachon, S. and Klassen, R. D. (2010), Empirical Studies in Closed-loop Supply Chains: Can We Source a greener Mousetrap?, in: Closed-Loop Supply Chains: New Developments to Improve the Sustainability of Business Practices, $1^{\text {st }}$ Ed., New York: Taylor \& Francis Group.

Verweij, H., Dang, N., Bonney, G. and Janse, B. (2008), Reverse Logistics: How to realise an agile and efficient reverse chain within the Consumer Electronic industry. In: Solutions, L. S. C. (ed.). Amsterdam: PriceWaterHouseCoopers.

Voss, C., Tsikriktsis, N. and Frohlich, M. (2002), Case research in operations management, International Journal of Operations \& Production Management, 22 (2), 195-219.

Weltevreden, J.W.J. (2008), B2C e-commerce logistics: the rise of collection-anddelivery points in The Netherlands.

Wood, S.L. (2001), Remote purchase environment: the influence of return policy leniency on two-stage decision processes, Journal of Marketing Research, 38(2), 157-69.

Xu, L., Li, Y., Govindan, K., \& Xu, X. (2015), Consumer returns policies with endogenous deadline and supply chain coordination, European Journal of Operational Research, 242(1), 88-99.

Yin, R.K. (2003), Case Study Research: Design and Methods, $3^{\text {rd }}$ edition, London: Sage Publications. 
Appendix A: interview protocol

\begin{tabular}{|c|c|c|}
\hline Topic & Question & Based on: \\
\hline \multirow{7}{*}{$\begin{array}{l}\text { Returns } \\
\text { networks, } \\
\text { channels } \\
\text { and } \\
\text { processes }\end{array}$} & $\begin{array}{l}\text { What are the supply networks in terms of } \\
\text { reverse logistics? }\end{array}$ & $\begin{array}{l}\text { Kumar and Putnam (2008); } \\
\text { Rogers and Tibben-Lembke } \\
\text { (1998). }\end{array}$ \\
\hline & $\begin{array}{l}\text { If the returned product will not go into } \\
\text { retail channel where does it go? How do } \\
\text { you share information with these channels? }\end{array}$ & $\begin{array}{l}\text { Blackburn et al. (2004); } \\
\text { Guide et al. (2006). }\end{array}$ \\
\hline & $\begin{array}{l}\text { What kind of return options/methods does } \\
\text { your company offer your consumers? }\end{array}$ & $\begin{array}{l}\text { Agatz et al. (2008); de Koster } \\
\text { (2001). }\end{array}$ \\
\hline & $\begin{array}{l}\text { How do you process returned products and } \\
\text { which actions do you take? Are there any } \\
\text { ways to improve this process? }\end{array}$ & $\begin{array}{l}\text { Rogers and Tibben-Lembke } \\
\text { (1998); de Brito and Dekker } \\
\text { (2004); Lambert et al. } \\
\text { (2011). }\end{array}$ \\
\hline & $\begin{array}{l}\text { How do you improve the streamlining of } \\
\text { product movement and what do you plan } \\
\text { in the next few years for this } \\
\text { improvement? }\end{array}$ & $\begin{array}{l}\text { de Brito and Dekker (2004); } \\
\text { Rogers and Tibben-Lembke } \\
\text { (1998); Guide and van } \\
\text { Wassenhove (2002). }\end{array}$ \\
\hline & $\begin{array}{l}\text { Where do all parties involved in the } \\
\text { reverse logistics network get the } \\
\text { information about what to do with the } \\
\text { returned items? }\end{array}$ & $\begin{array}{l}\text { Rogers and Tibben-Lembke } \\
\text { (1998); Blackburn et al. } \\
(2004) \text {. }\end{array}$ \\
\hline & $\begin{array}{l}\text { Can you think of anything that is in an } \\
\text { emergent need to increase the effectiveness } \\
\text { and efficiency in the reverse logistics } \\
\text { process? }\end{array}$ & $\begin{array}{l}\text { De Koster (2001); } \\
\text { Mukhopadhyay and } \\
\text { Setoputro (2004); Blackburn } \\
\text { et al. (2004). }\end{array}$ \\
\hline \multirow[t]{3}{*}{$\begin{array}{l}\text { Returns } \\
\text { policy }\end{array}$} & $\begin{array}{l}\text { Can you explain your return policy? What } \\
\text { are the refund conditions? }\end{array}$ & $\begin{array}{l}\text { Rogers and Tibben-Lembke } \\
\text { (1998); Lambert et al. } \\
\text { (2011); Weltevreden, (2008). }\end{array}$ \\
\hline & $\begin{array}{l}\text { How does the reverse logistics capabilities } \\
\text { of the company have impact on the return } \\
\text { policy? }\end{array}$ & $\begin{array}{l}\text { Blackburn et al., (2004); } \\
\text { Weltevreden (2008). Hwan } \\
\text { and Rho (2008). }\end{array}$ \\
\hline & $\begin{array}{l}\text { Do you know if the return policy } \\
\text { influences the volume of product returns, } \\
\text { and how? }\end{array}$ & $\begin{array}{l}\text { Blackburn et al. (2004); } \\
\text { Hwan and Rho (2008). }\end{array}$ \\
\hline $\begin{array}{l}\text { Gate- } \\
\text { keeping }\end{array}$ & $\begin{array}{l}\text { What are the processes to categorize the } \\
\text { return products? }\end{array}$ & De Brito and Dekker (2004). \\
\hline
\end{tabular}




\begin{tabular}{|c|c|c|}
\hline & $\begin{array}{l}\text { How do you determine which category the } \\
\text { product belongs to and which categories } \\
\text { are distinguished? What are the processes } \\
\text { after categorizing the returned products? }\end{array}$ & $\begin{array}{l}\text { De Brito and Dekker (2004); } \\
\text { Blackburn et al. (2004). }\end{array}$ \\
\hline & $\begin{array}{l}\text { What do you do with items that are not } \\
\text { compliant with the company return policy? }\end{array}$ & Lambert et al. (2011). \\
\hline & $\begin{array}{l}\text { How do you determine if product should } \\
\text { be allowed in the reverse stream? }\end{array}$ & $\begin{array}{l}\text { Lambert et al. (2011); Rogers } \\
\text { et al. (2002). }\end{array}$ \\
\hline Collection & $\begin{array}{l}\text { Who collects the returned products and } \\
\text { what parties are involved in the collection } \\
\text { process? Is there differentiation in costs? }\end{array}$ & $\begin{array}{l}\text { Lambert et al. (2011); } \\
\text { Weltevreden (2008). }\end{array}$ \\
\hline & $\begin{array}{l}\text { Who pays the delivery (collection) of the } \\
\text { product return? What is the fee? }\end{array}$ & $\begin{array}{l}\text { Bower and Maxham (2012); } \\
\text { Lambert et al. (2011); } \\
\text { Weltevreden (2008). }\end{array}$ \\
\hline & $\begin{array}{l}\text { Where are the returned items collected and } \\
\text { how do you determine the location of the } \\
\text { collection points? }\end{array}$ & $\begin{array}{l}\text { Lambert et al. (2011); } \\
\text { Browne } 2001 .\end{array}$ \\
\hline $\begin{array}{l}\text { Sorting, } \\
\text { inspection }\end{array}$ & $\begin{array}{l}\text { Who makes the decision about what to do } \\
\text { with the products that are returned? }\end{array}$ & $\begin{array}{l}\text { Lambert et al. (2011); Rogers } \\
\text { et al. (2002). }\end{array}$ \\
\hline $\begin{array}{l}\text { disposition } \\
\text { /redistri- }\end{array}$ & $\begin{array}{l}\text { Who does the inspection and what are the } \\
\text { next steps after the inspection? }\end{array}$ & Lambert et al. (2011) \\
\hline bution & $\begin{array}{l}\text { How do you share information on what has } \\
\text { been collected and what to do with the } \\
\text { collected product? Who are the parties } \\
\text { involved? }\end{array}$ & $\begin{array}{l}\text { Lambert et al. (2011); Rogers } \\
\text { et al. (2002). }\end{array}$ \\
\hline
\end{tabular}




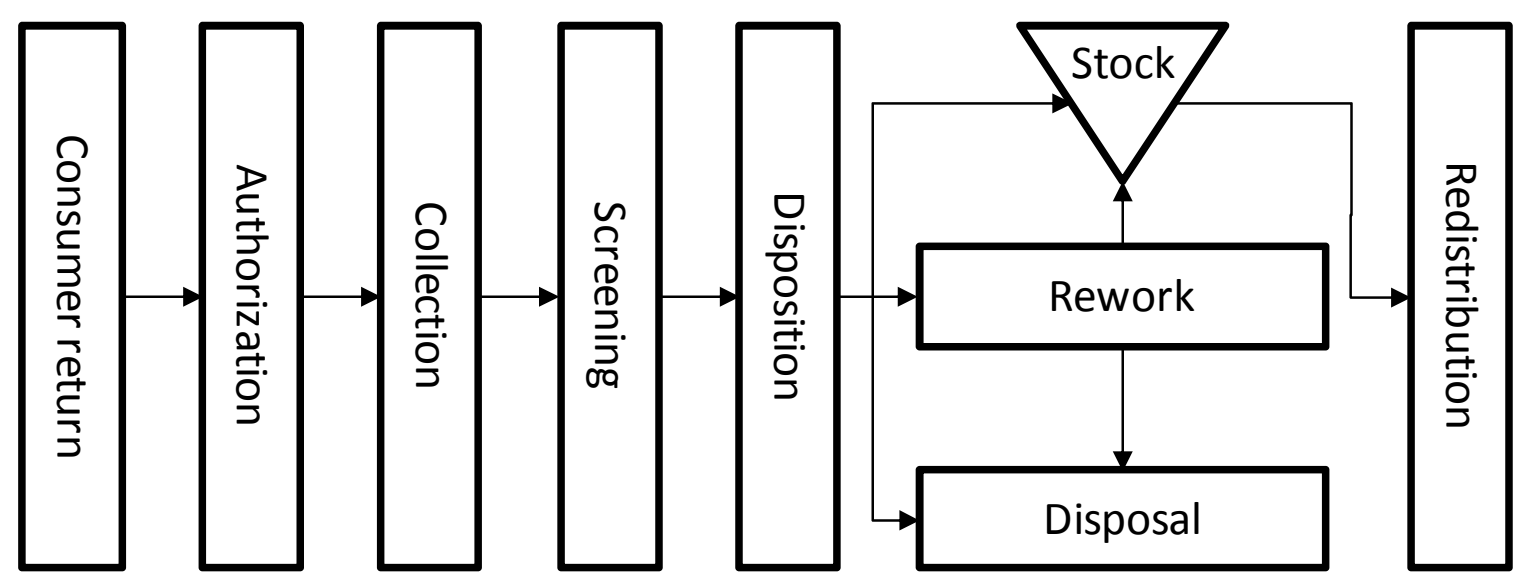

Figure 1: Reverse logistics process for commercial consumer returns

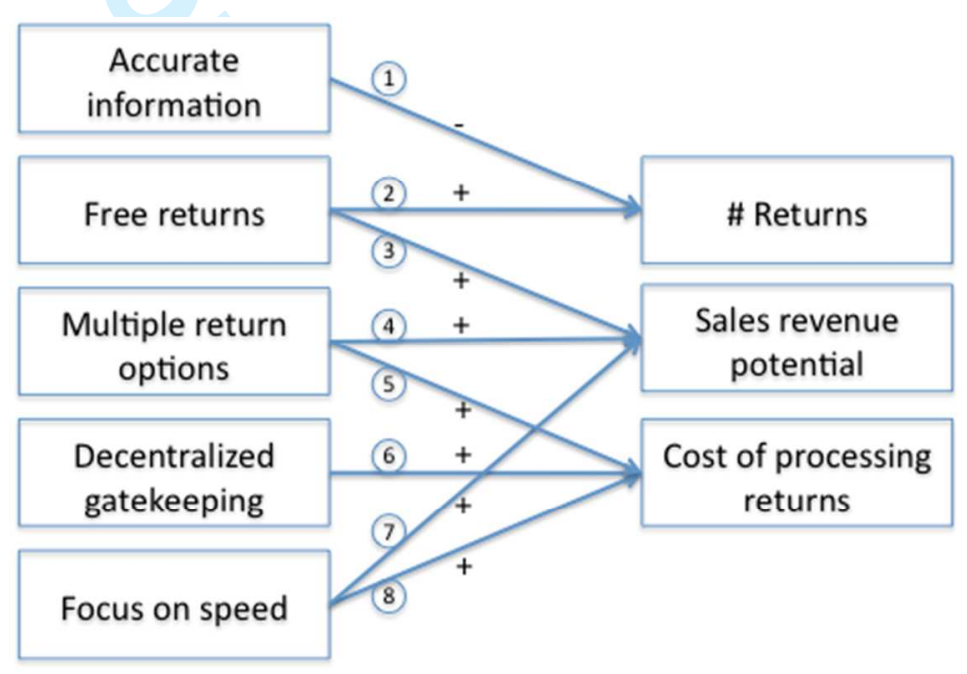

Figure 2. Conceptual model 